\title{
The US shale oil production, market forces and the US export ban
}

Ilayda Taneri

Department of Energy Economics, Policy and Security, Bilkent University, Ankara, Turkey

Nukhet Dogan

Department of Econometrics, Ankara Haci Bayram Veli University, Ankara, Turkey, and

M. Hakan Berument Department of Economics, Bilkent University, Ankara, Turkey
US shale oil production

Received 11 August 2020 Revised 11 November 2020 17 February 2021 Accepted 28 March 2021

\begin{abstract}
Purpose - The purpose of this paper is to use the novel data from the primary vision to determine the main financial and economic drivers of this revolutionary shale oil production and how these drivers changed after 2016 when the US removed its oil-exporting ban.

Design/methodology/approach - In this paper, the authors use the vector autoregressive model to assess the dynamic relationships among the Frac Count ( $\mathrm{FSCN}$ ) from the primary vision and the set of financial/macro-economic variables and how this dynamic relationship is altered with the effects of the US export ban before and after the lifting of the export ban.
\end{abstract}

Findings - The empirical evidence reveals that a positive shock to New York Mercantile Exchange, Standard and Poor's 500, rig count, West Texas Intermediate or the US ending oil stocks increase the FSCN but higher interest rates and oil production decrease the FSCN. After the US became one of the major oil producers, it removed its crude export ban in December 2015. The empirical evidence suggests that the shale oil industry gets more integrated with the financial system and becomes more efficient in its production process in the post-2016 era after the export ban was removed.

Originality/value - The purpose of this paper is to use the novel data from the primary vision to determine the main financial and economic drivers of this revolutionary shale oil production and how these drivers changed after 2016 when the US removed its oil-exporting ban.

Keywords Oil markets, Shale oil, Frac count, Time series analysis, Crude oil, Autoregressive, Non-conventional oil

Paper type Research paper

\section{Introduction}

In 2011, oil and gas production had begun in large quantities in oil-rich regions such as West Texas and North Dakota, reshaping the US and world oil and gas markets forever. This has been re-defined in the literature as the shale revolution. Shale oil (also known as tight oil) is

\section{JEL classification - Q40, Q41, Q43, Q49}

The authors would like to thank Matt Johson and Christian Mihai Tetileanu from Primary Vision for sharing their data and support throughout this work, Anita Akkas and Serkan Sahin for their helpful suggestions.

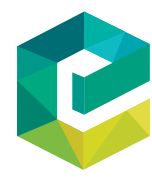

International Journal of Energy Sector Management Vol. 15 No. 6, 2021

pp. 1087-1103
C Emerald Publishing Limited
$1750-6220$

pp. 1087-1103
(c) Emerald Publishing Limited
$1750-6220$ 
IJESM 15,6

an unconventional type of oil, as its rock formations have low permeability. Thus, the shale oil production technique is different from the conventional oil production process and involves different dynamics. The purpose of this paper is to assess how the production of shale oil (as captured with the novel Frac Count (FSCN) data from primary vision) is affected by market factors and how the FSCN affects economic variables.

Tight oil is generally found under low permeability formations such as sandstone, carbonates and siltstone (Koplos et al., 2014), while shale oil is formed under highly organic mudstone and shale. Due to its rock formation, shale oil requires a different production process - a hydraulic fracking method to "open up" the rock formation for the oil to come out. According to the literature, oil is derived from oil shale that goes back a hundred years. Before the emergence of the shale oil boom, the term "shale oil" would be used for oil produced by oil shale. Previously, oil shale would be mined, crushed and heated to form "shale" oil, which is known as an ex-situ process. However, with recent technological improvements, operators no longer use the ex-situ process. Currently, without mining and crushing the rock itself, the operator conducts a heating process called pyrolysis directly to the oil shale, which is known as an in situ process.

The hydraulic fracking method needs to be combined with horizontal drilling for shale oil production. Horizontal drilling refers to the drilling technique that drills horizontally. In contrast, hydraulic fracturing refers to the final process of good operations where a chemical combination consisting of water, proppant and chemicals is injected into the shale rock, allowing the oil and the gas to flow out (The US Energy Information Administration, EIA, 2018a, 2018b). Technological advancements in the oil and gas sector have not only made untapped shale oil available for the US but also allowed shale oil to be produced in large quantities.

There are certain differences between the conventional and shale oil production processes. In terms of their cost analyzes, although the breakeven prices in shale oil have been dropping over the years, the breakeven prices for conventional oil has always been lower. The cost-per-barrel of conventional deposits changes depending on the country; however, one of the biggest conventional oil producers, Saudi Arabia, can still produce oil cheaply, sometimes under $\$ 10$. While in the Middle East and North Africa, oil can be produced as much as $\$ 20$ per barrel (Beattie, 2019). In the case of shale oil, the current breakeven price in the US (the biggest shale oil producers) ranges between $\$ 40$ and $\$ 60$; only a few producers can reduce their costs to less than $\$ 35$ (Hiller, 2020). In addition, production in shale oil wells tends to drop over time. Even though it is unclear whether shale oil wells have a shorter lifespan than a conventional oil well, the production phases of shale oil and conventional oil fields are different. For example, production wells in Permian's Wolfcamp shale declined close to 15\% after five years (WoodMackenzie, 2019). Similarly, a separate study conducted by Goldman Sachs refers to the shale oil industry, saying that "the most transformative areas of global oil supply are between 7 to 15 years" (Cunningham, 2018). Moreover, the quantity of shale oil produced in each field is different from conventional oil, as shale oil producers are smaller than conventional oil producers in terms of their capital structure. As a result, shale oil producers are more sensitive to interest rates, financial conditions and business cycles. As each operation field is smaller than the conventional ones, increasing or decreasing oil production is easier than for conventional wells. Consequently, they can respond to market conditions faster.

For the assessment of market factors for shale oil production, we used US data. There are several reasons for this decision. First, shale oil became a new source of oil supply for the US market, which reduces US oil dependency to a certain extent. The US, which was among the top oil importers, has now become among the top producers. The US has become the 
topmost crude oil producer $(13.2 \%)$ in the world, followed by Russia $(13 \%)$, Saudi Arabia $(12.6 \%)$, Iraq (5.6\%) and Canada (5.2\%). US crude oil is mainly supplied from five states: Texas (40\%) North Dakota (11.5\%), New Mexico (6.3\%), Oklahoma (5\%) and Alaska (4.5\%) (EIA, 2019a, 2019b). Although the US has decreased its import over the past few years, domestic production only accounts for $89 \%$, which is not enough to meet its oil demand. In 2018, the US produced 17.7 million barrels of oil per day, while it consumed around 20.5 million barrels of oil per day (EIA, 2019a, 2019b). The domestic market in the US also demands refined crude oil or petroleum products such as gasoline, diesel, heating oil and propane. Even though the US has become a top producer, due to the low sulfur content of shale oil, the US still needs to import heavy crude to blend with its light crude to meet its domestic demand.

Another reason for using US data is that oil and gas companies have provided new jobs for the US labor force, which resulted in slowly restoring its economy during the economic crisis after 2008. In this way, the US may have overcome the effects of the 2008 recession faster than other countries. The last and most important reason is that in addition to being the US among the top importers of crude oil, just recently the US has become one of the most important oil exporters.

The US had imposed a crude oil export ban after the Arab oil embargo on Israel and its allies in 1975. The US had enacted this ban to focus its domestic production on supplying its domestic oil market. Due to its oil production increase, the US removed this oil production ban in 2016. The purpose of this paper is to assess how the shale oil production measure responds to market forces and how the removal of the export ban on the US crude oil in December of 2015 affects these responses.

For this paper, we used the novel data from Primary Vision's Frac Spread Count from the US shale production, which considers the number of tools and equipment used to make an oil well to start production. The Frac Spread Count is similar to production data; however, there are certain differences between them. The critical difference is that the Frac Spread Count uses indicators such as chemical storage trucks, water trucks, sand, fluid storage tanks and wellheads to forecast US oil production. In contrast, the EIA data set is dependent on information provided by oil companies and can have measurement errors. If the EIA cannot retrieve the information which includes all the operators in a state, then it does not include those operators in the sample, and thus overall estimations will be biased. The EIA tries to tackle this problem using what it refers to as calculated based on the "most recently complete month" for each state. The EIA calculates taking the number of months between the latest reported month and the month in which the total production volume of a state is anticipated to be (EIA, 2018a, 2018b). Thus, the monthly production data set coming from the EIA is an estimation based on a six-month average and the estimates are subject to Type-II errors. Another important methodology flaw of the EIA monthly estimation is that unknown or deficient reporting or incorrectly handled mergers and property sales cause the relative standard error (the percentage of standard error which is the square root of the variance) to be large (EIA, 2018a, 2018b) The EIA states that the error term is not significantly large, but it is possible "to miss the bigger event" (EIA, 2018a, 2018b). Related to the missing information coming from states and concerning the methodology flaw of the EIA, some companies do not report their data or they report a value that is an expectation. If the EIA cannot retrieve and get a justifiable explanation from the company about suspicious or missing data, then the data is imputed at the time of estimation. The EIA derives imputed variables for oil production using a three-month average of the most recently available data set. In short, the EIA oil production methodology has quite significant lags changing for 
IJESM

15,6 each state. The EIA admits to being concerned about these flaws but explicitly states that they are aiming for $85 \%$ coverage of all states, which is a quite large error term.

In this paper, we use the vector autoregressive (VAR) model to assess the dynamic relationships among the FSCN from the primary vision and the set of financial/macroeconomic variables and how this dynamic relationship is altered with the effects of the US export ban before and after the lifting of the export ban.

In the oil sector-economic performance literature, unlike the current study, researchers mainly investigate the effect of oil prices on economic performance (Valadkhani and Smyth, 2017). To study the dynamic interactions among the set of variables, the VAR methodology has been used. Kilian (2009) initiated the workhorse model to analyze the effect of oil shocks on economic performance. This specification has been extended to assess various factors such as US stock prices (Kilian and Park, 2009), US bond prices (Kang et al., 2016), exchange rates (Chen et al., 2016) and economic policy uncertainty (Kang et al., 2016) are affected by the oil price shocks. There are few applied papers for shale oil and those examined the supply elasticity of shale oil with panel regression (Bjørnland et al., 2021 and Newell and Prest, 2019) or linear regression (Brown and Yücel, 2013).

Oil is extracted using different methods. Horizontal drilling and fractioning allow oil production in a different form. These new technologies revolutionized the energy world and made the US one of the most important oil producers and exporters. Shale oil production has different production dynamics and companies that produce shale oil have a different corporate structure. The purpose of this paper is to use the novel data from the primary vision to determine the main financial and economic drivers of this revolutionary shale oil production and how these drivers changed after 2016 when the US removed its oil-exporting ban. The contribution of this paper is three-fold. First, this is the first empirical study that examines the effect of so many market forces on shale oil production. Second, it studies the effect of removing the US export ban on this interaction of market forces with shale oil. Third, it uses the novel data from the primary vision to assess shale oil production for the US.

This article also assesses how market factors affect (shale/tight) oil production, which has not been explicitly discussed in the literature. In our model, we looked at how the US Nationwide FSCN is affected by 10 macro-financial variables and how FSCN affects these variables in the full sample. The same analysis was conducted for the pre-ban (2014-2015) and post-ban (2016-2020) eras. The empirical evidence reveals that a positive shock to New York Mercantile Exchange (NYMEX), Standard and Poor's 500 (S\&P500), rig count, West Texas Intermediate (WTI) or the US ending oil stocks increase the FSCN but higher interest rates and oil production decrease the FSCN. After the US became one of the major oil producers, it removed its crude export ban in December 2015. The empirical evidence suggests that the shale oil industry gets more integrated with the financial system and becomes more efficient in its production process in the post-2016 era after the export ban was removed.

Section 2 will be discussing the literature. In Section 3, we will discuss in detail the data and methodology which is used in this paper. In Section 4, we report the empirical evidence derived from our model and in Section 5, we conclude this paper.

\section{Literature review}

The initial literature focus is on the economic benefits and consequences of shale oil. A group of authors argues that the shale oil boom has contributed to the US gross domestic product (GDP) and created jobs (Brown and Yücel, 2013; Eberhart, 2011; Marfone, 2013); while other authors addressed its environmental impacts such as being a threat to ecological 
habitats (Brittingham et al., 2014; Leahy, 2014; Souther et al., 2014) and health consequences such as water pollution (Banerjee, 2015; Zhang and Yang, 2015). The literature also elaborates the competitiveness between the US and the OPEC producers (Ramady and Mahdi, 2015; Lemons, 2014; Salameh, 2013); while a few studies exclusively analyze shale oil's potential impact on African oil producers (Brune, 2015; Ogunyiola, 2015).

More detailed studies analyzed the effect of shale oil on world oil prices. Some authors argued that shale oil was one of the causes of the world crude oil price crash in 2014 (Alvares and Nino, 2017; Baffes et al., 2015; Ellwanger et al., 2017); while some argue that there is not enough evidence to support the shale oil boom impact on 2014 crude oil prices (Baumeister and Kilian, 2016; Kilian, 2017; Kilian, 2015; Manescu and Nuno, 2015). However, a larger number of studies are in agreement that shale oil had a negative impact on crude oil prices (Frondel and Horvath, 2019). Similarly, an expected increase in shale oil supply can decrease crude oil prices (Fueki et al., 2018).

Related to the world crude oil prices literature, the chief economist of British Petroleum also argued that although shale oil is more responsive than conventional oil to price shocks, it is also more dependent on banking and financial systems which can expose oil markets to financial shocks and financial shocks increase price volatility in the oil market (Dale, 2015). The recent developments in the US banking sector show the potential dilemma of the US which Dale had signaled; Gupta (2019) states that the lack of credit was a heavy blow to the already struggling shale industry. These developments will be manifest in the US economy as the oil and gas sector contributes 8\% to the GDP (American Petroleum Institute, 2018).

The characteristics of shale oil production are important to a better understanding of the effects of market forces on oil production. Shale oil production is more capital intensive than conventional oil production. Thus, oil companies have to drill more wells to cover their costs. In other words, they have to look for other wells without having reaped the benefits from their earlier investment. One of the weaknesses of shale oil production is that as soon as a well starts production, the production reaches its peak production in the first week (Maugeri, 2013; McCracken, 2015). Additionally, if oil prices drop more than the marginal cost of oil production, the companies would slow down their operations by shutting down wells and or could terminate them (Difiglo, 2014). Thus, shale oil production is more sensitive to market forces than conventional oil production. Regarding the price responsiveness of shale oil production, Bjørnland et al. (2021) and Newell and Prest (2019) find that shale wells are more price elastic than conventional wells.

\section{Data and methodology}

To assess the dynamic relationships among national FSCN and any set of financial and macro-economic variables, we use a VAR model with 639 weekly observations starting from 2014 and ending in March 2020. The set of financial and macro-economic variables include the NYMEX oil price future contracts (NYMEX), S\&P500, oil price for WTI, Brent/WTI price $(B R E N T / W T I)$, the refinery utilization rate (UTIL), the oil export/import ratio (EXP/ $I M P)$ of the US, the US crude oil ending stock (STOCK), the US crude oil production $(P R O D)$, the federal funds rate $(R)$ and the Rig count $(R I G)$. All the variables used are given as logarithms except for federal funds and utilization rates.

To assess how the FSCN is affected by various market statistics in a dynamic framework and how the FSCN affects these variables, we used a VAR model. This dynamic model consists of an 11-equation (11)-variable linear specification to explain the current variables of interest with their lag values (Stock and Watson, 2001). $X_{t}$ is an $11 x 1$ vector of endogenous variables and can be partitioned as $\left[Y_{t}, S_{t}\right] . Y_{t}$ is the vector for the market forces' variables. $S_{t}$ is for the shale oil production measures. $Y_{t}$ consists of NYMEX, 
IJESM

15,6

1092

S\&P500, R, PROD, WTI, BRENT/WTI, UTIL, EXP/IMP and STOCKS. $S_{t}$ is for the FSCN and RIG.

A VAR model can be written as the following:

$$
\Phi(L) . X_{t}=u_{t}
$$

where $L$ is the lag operator, $u_{t}$ is the $\mathrm{n} x 1$ vector of unobservable residuals with the diagonal variance-covariance matrix of $\Omega$. If one premultiplies equation (1) with $\Phi_{0}^{-1}$, then

$$
\mathrm{A}(\mathrm{L}) Y_{t}=\varepsilon_{t}
$$

In a more explicit form

$$
\left[\begin{array}{ll}
\left(\Phi_{0}^{-1}\right)_{Y Y} & \left(\Phi_{0}^{-1}\right)_{Y S} \\
\left(\Phi_{0}^{-1}\right)_{S Y} & \left(\Phi_{0}^{-1}\right)_{S S}
\end{array}\right] \Phi(\mathrm{L})\left[\begin{array}{c}
Y_{t} \\
S_{t}
\end{array}\right]=\left[\begin{array}{ll}
\left(\Phi_{0}^{-1}\right)_{Y Y} & \left(\Phi_{0}^{-1}\right)_{Y S} \\
\left(\Phi_{0}^{-1}\right)_{S Y} & \left(\Phi_{0}^{-1}\right)_{S S}
\end{array}\right]\left[\begin{array}{c}
u_{Y, t} \\
u_{S, t}
\end{array}\right]
$$

Following the Cholesky Identification scheme, we assume $\Phi_{0}^{-1}$ is a lower triangle matrix. To capture the dynamic effect of market forces on shale oil production measures, then equation (1) can be written as

$$
X_{t}=\Theta(L) U_{t}
$$

where $\Theta(L)$ is an infinite order polynomial of the lag operator of $L$. In this paper, impulse response function analyzes (IRF) are used for inferences. We have used the Cholesky decompression method for identifying shocks for the IRF's. Ordering variables in a Cholesky decomposition is important because all the variables in the equation are affected by the preceding variables concurrently, but at the same time do not get affected by the next variable in the equation. The variables are ordered such that financial variables are placed first, production data is second and price data is set third, while trade and stock variables are placed last. For each group, we ordered from the most to the least volatile. The lag order chosen for the VAR specification is two, as proposed by the Akaike Information Criteria. The estimates of $\Theta(\mathrm{L})$ give the impulse responses.

The primary variable of this paper, $F S C N$, was gathered by considering the equipment that is needed to complete an oil well operation - chemical storage trucks, water trucks, sand and frac fluid storage tanks, wellheads, frac blenders and frac pumps (Primary Vision, 2019). FSCN considers the time when an oil well is completed and starts production. PV's data set considers the shale basins in 18 regions of the US. The PV's data set also includes $R I G$, which captures the number of oil wells being drilled in a particular field. It is important to mention that $R I G$ does not mean production. It merely shows how many wells have been drilled in a particular region. As production is realized very soon after the operation is started, the drilling precedes the production by a very short period of time.

NYMEX Contract 4 is a future price of WTI that will be delivered in four months in the oil market and buyers use NYMEX contracts as a hedging tool to minimize their risk (Reiff, 2020). $P R O D$ is defined as the total US crude oil production in 1,000 barrels per day. (BRENT/WTI) is the relative crude oil spot price of Brent to WTI. UTIL is known as the refinery utilization rate (the percentage showing how much refineries derive from raw oil in 
the USA). The US oil export/import ratio is denoted by EXP/IMP. The US ending oil stock is denoted by STOCK. All these data are taken from the EIA.

Moreover, $R$ is used for the federal funds rate taken from the St. Louis Federal Reserve Economic Data Delivery System. Finally, the S\&P500, an index consisting of 500 US companies, is taken from Yahoo finance.

We have 11 variables in our VAR specifications. There might be a high degree of correlations among these 11 variables and the estimates might be affected by these high degree correlations. Thus, we provide the estimated correlation coefficients among these production variables for the full sample and two sub-samples in Tables $1-3$. The first sub-sample for 2104-2015 when the oil export ban was effective and the second sub-sample for the export ban was removed. We are interested in the effects of FSCN and how FSCN affects the remaining 10 variables. Thus, the correlation of coefficients of FSCN with the remaining 10 variables is interest. For the full sample and the second sub-sample, the correlation coefficients of FSCN with S\&P500 are above the conventional $80 \%$. Moreover, the correlation coefficient between FSCN and Exp/IMP ratio for the second sub-sample. However, the remaining 27 correlation coefficients were below the conventional $80 \%$ level. Thus, we can claim that the impulse responses that we gather from our VAR specifications are efficient.

\begin{tabular}{|c|c|c|c|c|c|c|c|c|c|c|c|c|}
\hline Variables & NYMEX & S\&P500 & $\mathrm{R}$ & $\mathrm{FSCN}$ & RIG & PROD & WTI & $\begin{array}{l}\text { BRENT/ } \\
\text { WTI }\end{array}$ & UTIL & EXP/IMP & STOCK & \\
\hline NYMEX & 1.00 & & & & & & & & & & & \\
\hline S\&P500 & -0.12 & 1.00 & & & & & & & & & & \\
\hline FSCN & 0.07 & -0.95 & 1.00 & & & & & & & & & \\
\hline $\mathrm{R}$ & 0.59 & 0.46 & -0.47 & 1.00 & & & & & & & & \\
\hline RIG & 0.79 & -0.13 & 0.09 & 0.76 & 1.00 & & & & & & & \\
\hline PROD & -0.12 & 0.88 & -0.84 & 0.43 & -0.02 & 1.00 & & & & & & \\
\hline WTI & 1.00 & -0.06 & 0.01 & 0.63 & 0.78 & -0.07 & 1.00 & & & & & \\
\hline BRENT/WTI & 0.19 & 0.49 & -0.49 & 0.53 & 0.32 & 0.59 & 0.20 & 1.00 & & & & Table 1. \\
\hline UTIL & -0.03 & 0.20 & -0.15 & 0.13 & 0.02 & 0.19 & 0.00 & 0.01 & 1.00 & & & Correlation \\
\hline EXP/IMP & -0.31 & 0.90 & -0.84 & 0.30 & -0.24 & 0.89 & -0.26 & 0.44 & 0.21 & 1.00 & & coefficients among 11 \\
\hline STOCK & -0.76 & -0.03 & 0.07 & -0.69 & -0.84 & -0.19 & -0.76 & -0.37 & -0.07 & 0.05 & 1.00 & variables: 2014-2020 \\
\hline
\end{tabular}

\begin{tabular}{|c|c|c|c|c|c|c|c|c|c|c|c|c|}
\hline \multirow[b]{2}{*}{ Variables } & \multirow[b]{2}{*}{ NYMEX } & \multirow[b]{2}{*}{ S\&P500 } & \multirow[b]{2}{*}{$\mathrm{R}$} & \multirow[b]{2}{*}{ FSCN } & \multirow[b]{2}{*}{ RIG } & \multirow[b]{2}{*}{ PROD } & \multicolumn{3}{|c|}{ BRENT/ } & \multirow[b]{2}{*}{ EXP/IMP } & \multirow[b]{2}{*}{ STOCK } & \\
\hline & & & & & & & WTI & WTI & UTIL & & & \\
\hline NYMEX & 1.00 & & & & & & & & & & & \\
\hline S\&P500 & -0.67 & 1.00 & & & & & & & & & & \\
\hline FSCN & -0.21 & -0.21 & 1.00 & & & & & & & & & \\
\hline $\mathrm{R}$ & 0.80 & -0.45 & -0.53 & 1.00 & & & & & & & & \\
\hline RIG & 0.83 & -0.56 & -0.48 & 0.96 & 1.00 & & & & & & & \\
\hline PROD & -0.83 & 0.88 & -0.09 & -0.58 & -0.70 & 1.00 & & & & & & Table 2 \\
\hline WTI & 1.00 & -0.67 & -0.20 & 0.80 & 0.83 & -0.83 & 1.00 & & & & & 1abie 2. \\
\hline BRENT/WTI & -0.04 & 0.02 & -0.11 & -0.08 & -0.08 & 0.01 & -0.07 & 1.00 & & & & Correlation \\
\hline UTIL & -0.25 & 0.46 & 0.07 & -0.21 & -0.28 & 0.45 & -0.24 & -0.14 & 1.00 & & & coefficients among \\
\hline EXP/IMP & -0.74 & 0.84 & -0.12 & -0.48 & -0.58 & 0.90 & -0.73 & -0.13 & 0.44 & 1.00 & & the 11 variables: \\
\hline STOCK & -0.82 & 0.64 & 0.31 & -0.90 & -0.96 & 0.75 & -0.82 & 0.11 & 0.23 & 0.58 & 1.00 & 2014-2015 \\
\hline
\end{tabular}




\section{IJESM \\ 15,6}

1094

\section{Empirical results}

To estimate how the FSCN calculations of the shale oil production in the US are affected by economic variables, Figure 1 reports the impulse responses of FSCN when one-standarddeviation-shock is given to the 11 variables considered in the system. Figure 2 shows the impulse responses of these 11 variables when the one-standard-deviation shock is given to $F S C N$. The solid blue line is for the impulse responses and the two dotted red lines are for $95 \%$ confidence intervals. If the red line includes zero, then we cannot reject the null hypothesis that the impulse response is zero for that particular period or is not statistically significantly different from zero.

Figure 1 suggests that a one-standard-deviation shock to NYMEX, S\&P500, RIG, WTI and $S T O C K S$ increase the $F S C N$ in a statically significant fashion at least for one period. This effect is longer lasting for NYMEX oil contracts, RIG and STOCKS. The impact of higher stock returns in S\&P500 makes financing oil production easier. As for S\&P500, FSCN initially increases, then the curve gradually declines until its 29 th week. After the 30th week, it passes into the negative zone.

Table 3.

Correlation coefficients among the 11 variables: 2016-2020

\begin{tabular}{|c|c|c|c|c|c|c|c|c|c|c|c|}
\hline Variables & NYMEX & S\&P500 & $\mathrm{R}$ & FSCN & RIG & PROD & WTI & $\begin{array}{c}\text { BRENT/ } \\
\text { WTI }\end{array}$ & UTIL & EXP/IMP & STOCK \\
\hline NYMEX & 1.00 & & & & & & & & & & \\
\hline S\&P500 & 0.77 & 1.00 & & & & & & & & & \\
\hline FSCN & -0.65 & -0.93 & 1.00 & & & & & & & & \\
\hline $\mathrm{R}$ & 0.70 & 0.82 & -0.76 & 1.00 & & & & & & & \\
\hline RIG & 0.64 & 0.79 & -0.72 & 0.95 & 1.00 & & & & & & \\
\hline PROD & 0.54 & 0.86 & -0.86 & 0.66 & 0.68 & 1.00 & & & & & \\
\hline WTI & 0.99 & 0.80 & -0.68 & 0.73 & 0.67 & 0.56 & 1.00 & & & & \\
\hline BRENT/WTI & 0.50 & 0.74 & -0.75 & 0.69 & 0.70 & 0.76 & 0.50 & 1.00 & & & \\
\hline UTIL & 0.19 & 0.19 & -0.21 & 0.23 & 0.24 & 0.15 & 0.23 & 0.05 & 1.00 & & \\
\hline EXP/IMP & 0.64 & 0.90 & -0.89 & 0.72 & 0.72 & 0.92 & 0.66 & 0.79 & 0.15 & 1.00 & \\
\hline STOCK & -0.67 & -0.82 & 0.76 & -0.72 & -0.69 & -0.81 & -0.68 & -0.66 & -0.24 & -0.81 & 1.00 \\
\hline
\end{tabular}

Figure 1.

Response of the FSCN to 11 variables between 2014 and 2020
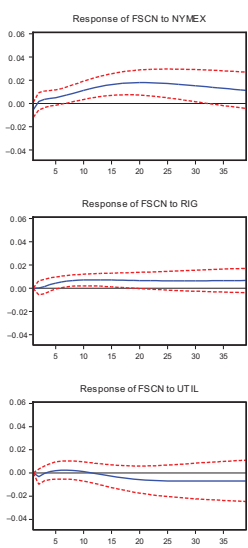

Response to Cholesky One S.D. (d.f. adjusted) Innovations \pm 2 S.E.

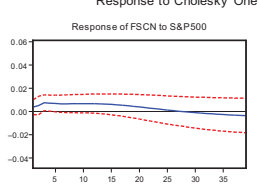

Response of FSCN to PROD

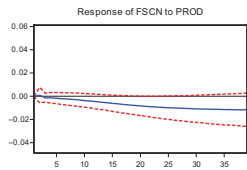

Response of ESCN to EXPM

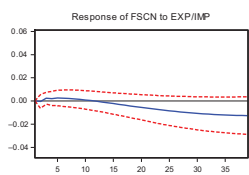

Response of ESCN to

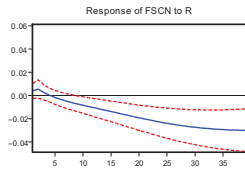

Response of ESCN to WTI

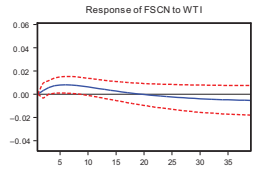

esponse of FSCN to STOCK

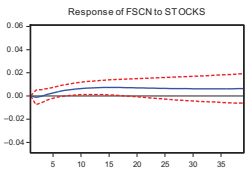

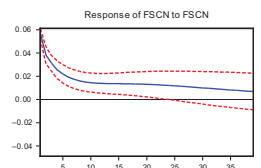

Dense of ESCN to BPENT NTI

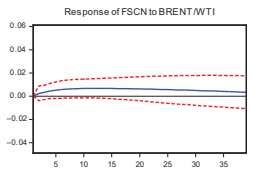




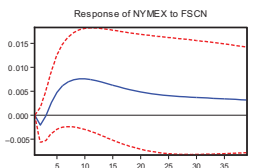

Response of RIG to FSCN

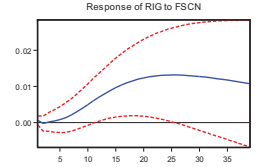

Response of UTL to FSCN

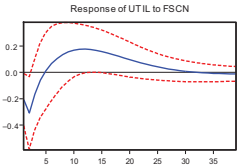

Response to Cholesky One S.D. (d.f. adjusted) Innov ations \pm 2 S.E.

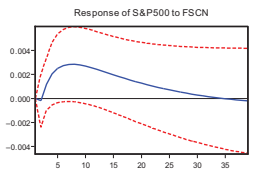

Response of PROD to FSCN

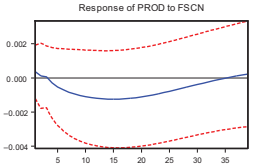

Response of EXPIIMP to FSCN

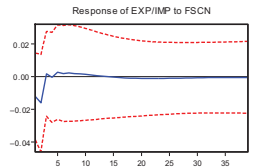

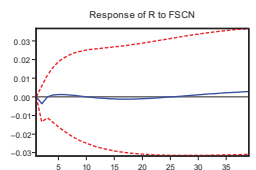

Response of WTI to FSCN

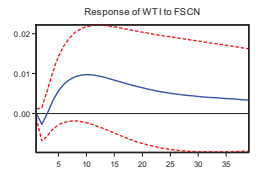

Response of STOCKS toFSCN

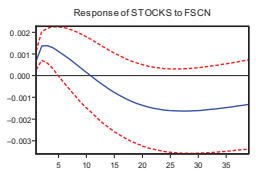

US shale oil production

1095
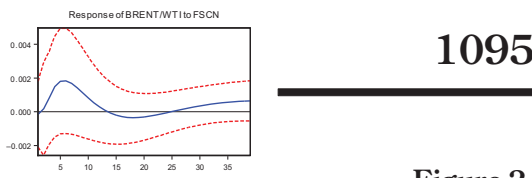

Figure 2.

Response of 11 variables to $\mathrm{FSCN}$ between 2014 and 2020

The increasing effect of higher oil prices captured by NYMEX and WTI on FSCN also makes sense, as the operation would be more profitable with higher oil prices. Oil and gas companies use NYMEX futures contracts for oil prices, as they hedge their risks to cover possible losses (Chen, 2020). NYMEX futures contracts, due to their transparent price mechanism and liquidity, are taken as an international benchmark in crude oil markets, while WTI spot prices are historically known to be more volatile (Securities and Exchange, 2008). NYMEX affects FSCN positively between the 4th and 32nd weeks, while other periods are not statistically significant. WTI affects FSCN positively between the 3rd and 10th weeks over a shorter duration. This is a parallel result to that seen in Bjørnland et al. (2021) and Newell and Prest (2019).

The above evidence indicates that companies tend to use NYMEX futures, instead of WTI spot prices, to lower their production. Therefore, when NYMEX increases, this generally means FSCN will also increase because the future prices are attractive, making sellers want to sell their commodities. Thus, the oil and gas companies would be motivated to explore new wells and upgrade their existing wells to increase their margin, as observed in the figure.

The relative price of BRENT/WTI also increases the FSCN. This might be due to the higher export potential of US oil. Higher US STOCKS may also increase FSCN. The effect of STOCKS is permanent; it dies out after 46 periods (not reported) and this is statically significant for the first 18 periods. It can be seen that as STOCKS increases, FSCN starts to increase after the 7 th period until the 18 th period in a statically significant function. Shock to STOCKS affects FSCN positively between the 7 th and 18 th weeks.

On the other hand, higher interest rates and oil production decrease the FSCN. These make sense because as the cost of borrowing increases so does the cost of production, including production resulting from conventional oil fields. $R$ affects $F S C N$ with an increase initially; however, the impulse response declines gradually after the 3rd week. Higher production can be taken as an indicator of lower excess demand and shale oil production is reduced. This decrease is statistically significant between the 17 th and 30 th weeks.

In short, FSCN gradually increases when a shock is given to NYMEX and WTI. Second, as a result of the shock given to $S \& P 500, F S C N$ increases until the 30 th week, after which it drops down into the negative zone. However, after the 30th week is statically insignificant and when a shock is given to R, FSCN declines sharply. Last, as the cost of financing 
IJESM

15,6

1096

increases, FSCN decreases. These findings are sensible. The rest of the variables (except RIG, WTI and STOCKS) are statistically insignificant. Although these three variables are overall statically insignificant as well, there are periods observed in these variables where they affect $F S C N$ positively, which is statistically significant.

The response of change in FSCN to a one-standard-deviation-shock to PROD is positive at the beginning after which there is a downturn and it is statistically insignificant which is in line with the responses of Huang and Mollick (2020) for world oil production (excluding the USA) but statistically significant just at month one.

Figure 2 suggests that a one-standard-deviation shock to FSCN increases RIG, UTIL and $S T O C K S$ in a statically significant function. $R I G$ is statistically significant between the 11 th and 26th periods, while for UTIL it is between the 13th and 15th periods at the margin and for STOCKS it is the first seven periods. UTIL starts from the negative zone, followed by a sharp increase where it passes into the positive zone between the 2nd and 10th weeks. Then UTIL's curve gradually declines, dropping down to the negative zone from the 36 th week. EXP/IMP also starts from the negative zone but sharply increases passing into the positive zone starting from 3rd and 4th weeks, then the curve gradually declines to drop back to the negative zone from 6 th till the 24th week. From the 25th week onwards the curve stays close to zero. STOCKS starts from the positive zone but declines gradually into the negative zone starting from the 3rd week. These results are sensible as there may be more than one rig in each FSCN. Thus, companies are likely to increase production, the rig count and utilization rate. Additionally, higher FSCN can be taken as an indicator of crude production and this increases crude STOCKS. The response of S\&P500 to a shock in the FSCN is negative for the initial level; then it turns positive, but all of them are statistically insignificant. The statistically insignificant estimates are parallel to Huang and Mollick (2020); their negative response for $S \& P 500$ was statistically significant just at the initial level.

In 1975, the US imposed a ban on crude oil exports as a response to the Arab oil embargo. With the shale revolution, the US increased its oil production. Thus, starting in 2016, the US lifted its export ban. To see if this ban had an effect on the FSCN, we split the sample into pre-ban 2014-2015 and post-ban 2016-2019 eras. Figures 3 and 4 report the impulse response before the ban, whereas Figures 5 and 6 show the results for 2016-2019 after the ban was lifted. The estimates are mostly robust with a few exceptions. When we look at the effects of 11 variables, then we observe that NYMEX contracts, which were negative

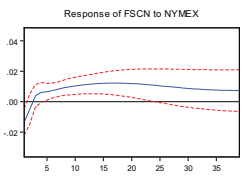

Response of FSCN to RIG

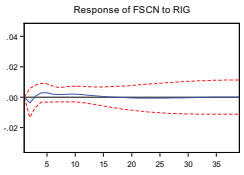

Response of FSCN to UTIL

Figure 3.

Response of FSCN to 11 variables between 2014 and 2015
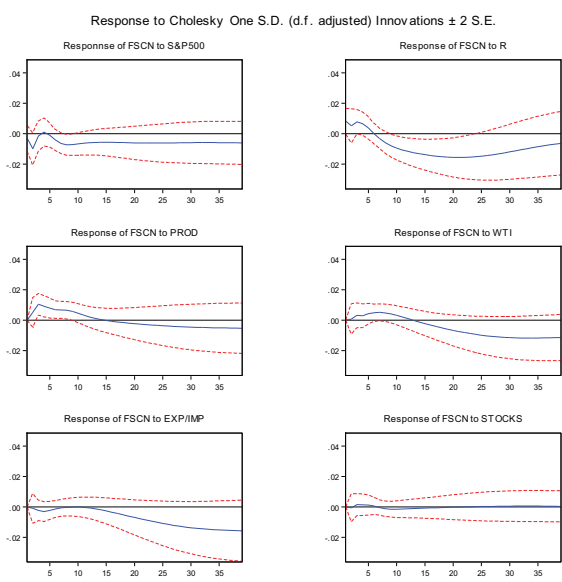
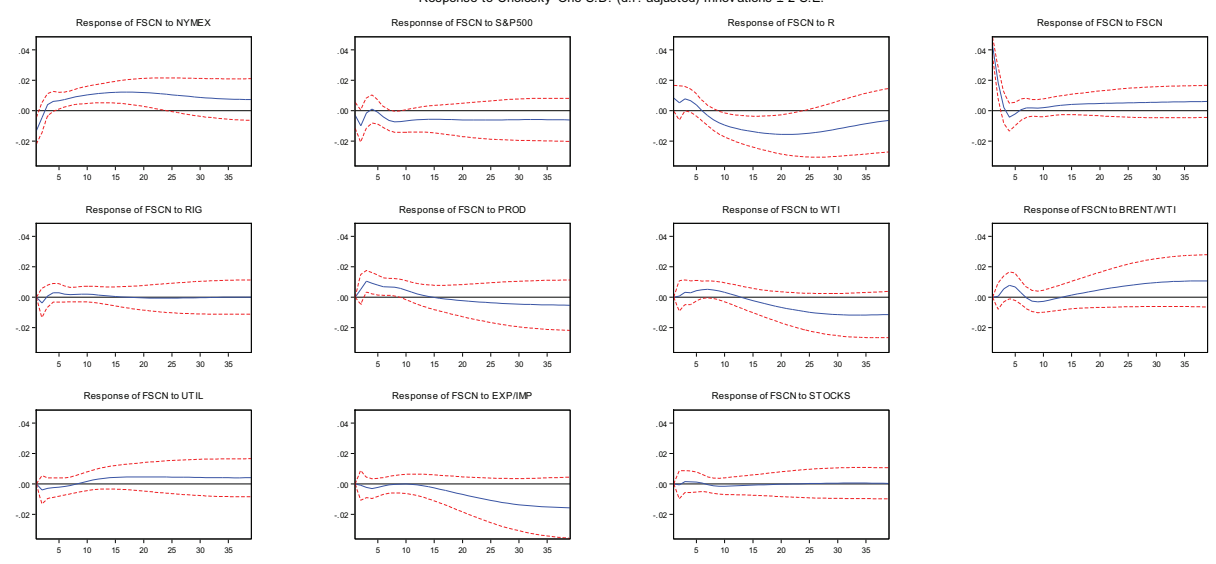

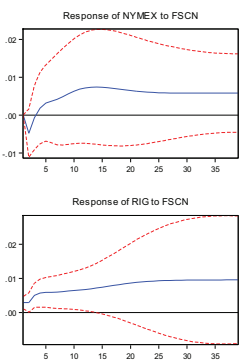

Response of UTIL to FSCI
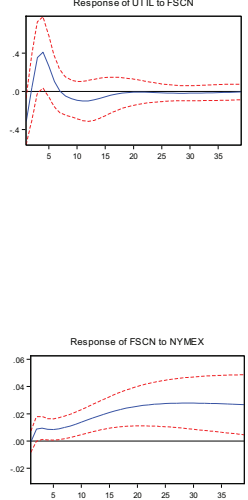

Response of FSCN to RIC

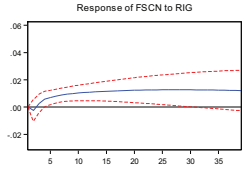

Response of FSCN to UT

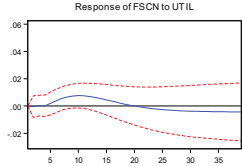

Cholesky One S.D. (d.f. adjusted) Innovations \pm 2 S.E.
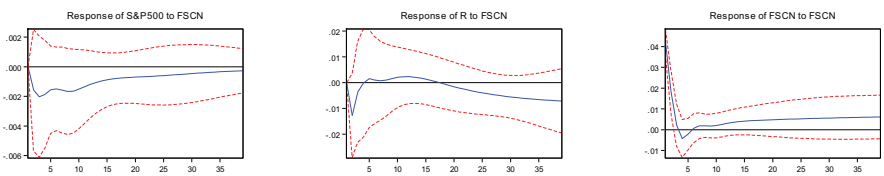

Response of ProD to $\mathrm{FSCN}$

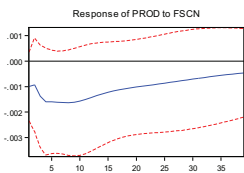

Response of EXPIIMP to FSCI
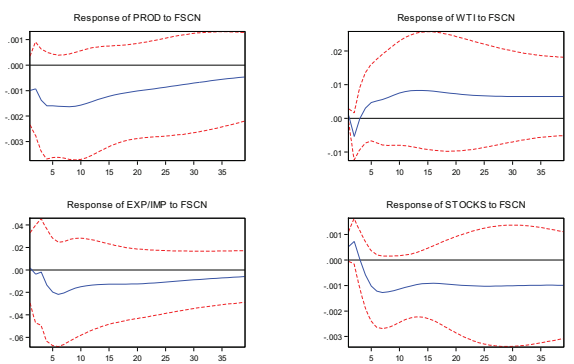

Response of STOCKS to FSC
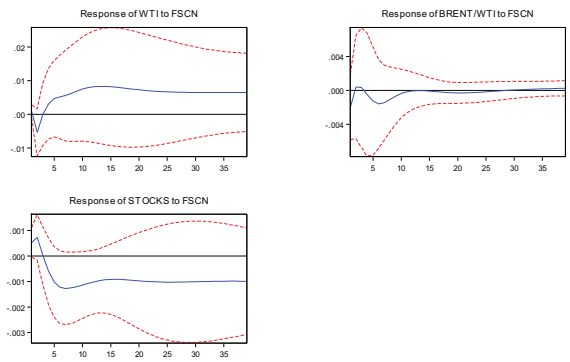

1097

Figure 4.

Responses of 11 variables to $\mathrm{FSCN}$ between 2014 and

2015
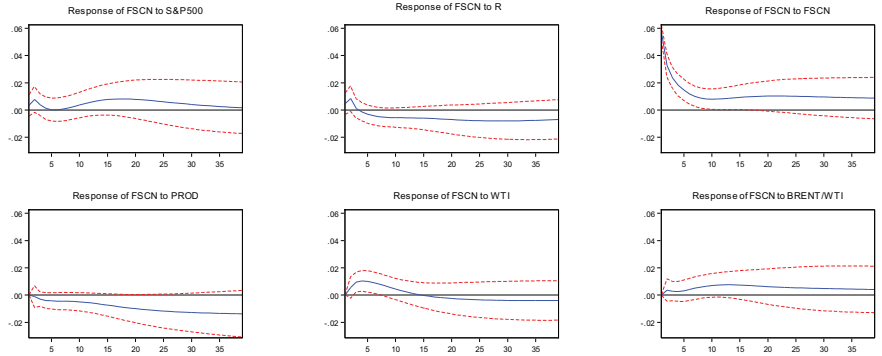

Response of FSCN to EXPIMP

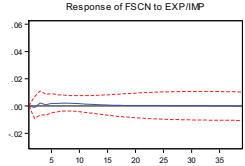

Response of FSCN to WTI

esponse of FSCN to
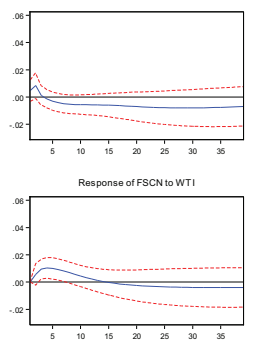

Response of FSCN to STOCKS

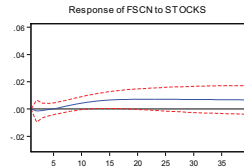

Figure 5.

Response of FSCN to 11 variables between 2016 and 2020

initially during the ban, positively affect the FSCN after the removal of the ban. RIG did not have a statistically significant effect during the ban, but Rig count has a statistically significant effect on FSCN after the removal of the ban. During the ban, production had a positive effect on $F S C N$, but this effect disappears after the ban was removed. The negative and statistically significant effect of interest rates disappears after the removal of the export ban. Finally, even if it is not statistically significant after the removal of the ban, S\&P500 affects positively but not negatively affect the FSCN. All these suggest that the shale oil industry has become more integrated with the financial market and has gotten more efficient in its production in the post-2016 era after the export ban was removed[1]. 
IJESM

15,6

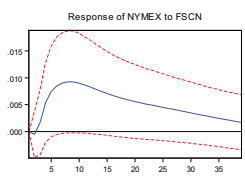

1098

Figure 6.

Response of 11 variables to $\mathrm{FSCN}$ between 2016 and 2020

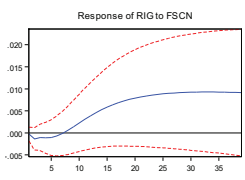

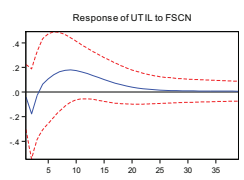

Response of TIGHT OIL to NYMEX

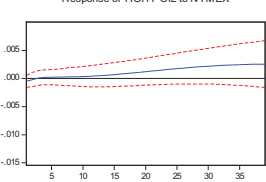

Response of TIGHT OIL to RIG

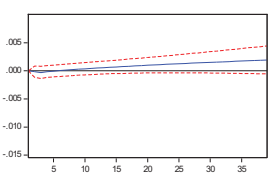

Response of TIGHT OIL to UTIL

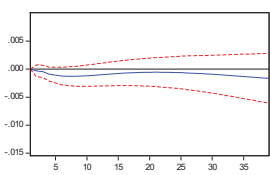

Response to Cholesky One S.D. (d.f. adjusted) Innovations \pm 2 S.E.

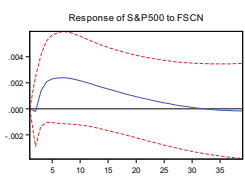

Response of PRoD to FSCN

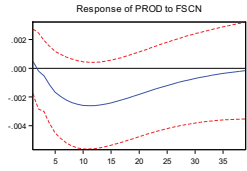

Response of EXPIIMP to FSCN

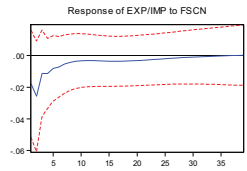

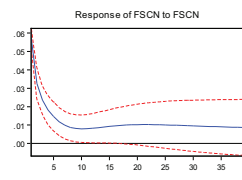

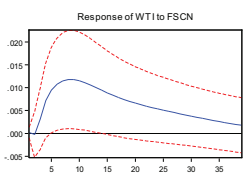

Response of STOCKS to FSCM

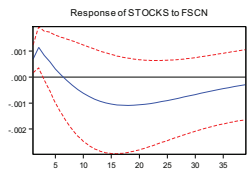

Response of BRENT WTI It FSCN

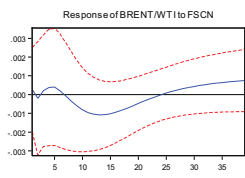

Figure 7.

Response of 11 variables to tight oil between 2014 and 2020

The tight oil data is available from the EIA of the US. As stated in the introduction, this data is subject to measurement errors. Nevertheless, we repeat the exercise for the full sample using the tight oil data rather than FSCN. The impulse responses are reported in Figures 7 and 8 . The impulse responses are mostly parallel but have wider confidence bands. This further validates the use of FSCN as a production measure of shale oil in our study.

\section{Conclusion}

The shale oil revolution after 2011 changed both US and world oil markets. This paper studies the market determinants of shale oil statistics using a more direct measure of shale oil. Thus, we use the novel Frac Spread Count data from Primary Vision for US shale production. The empirical evidence suggests that a positive shock to NYMEX oil prices, 

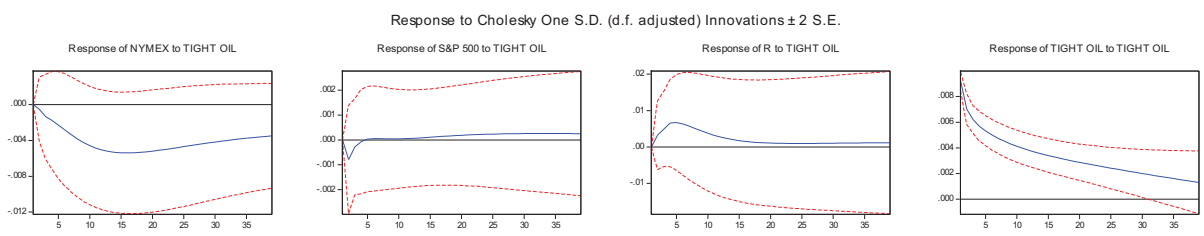

US shale oil

Response of RIG to TIGHT OIL

Response of PROD to TIGHT_OIL
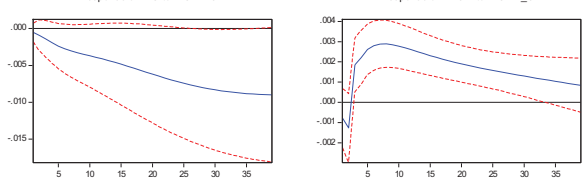

Response of WTI to TIGHT_OIL

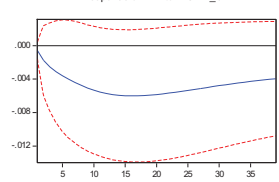

Response of BRENTNTI to TIGHT O

1099

Response of UTLL to TIGHT OIL

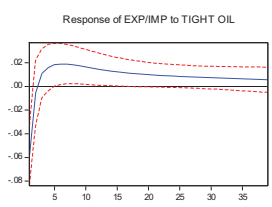

Response of STOCKS to TIGHT OLL
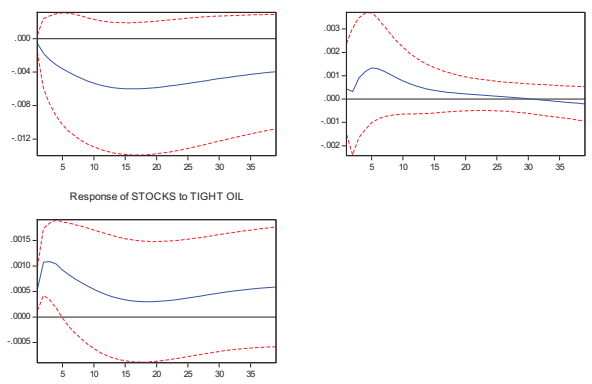

Figure 8.

Response of tight oil to 11 variables between 2014 and

2020

S\&P500, rig count, WTI and ending oil stocks increases the FSCN but higher interest rates and production decrease the FSCN. However, the effects of the FSCN are limited. It increases rig counts and ending oil stocks.

After the US became one of the major oil producers, it removed its crude export ban in December 2015. The empirical evidence suggests that the shale oil industry is getting more integrated with the financial system and is becoming more efficient in its production process in the post-2016 era after the export ban was raised.

Following greater integration of shale oil production with the financial markets after the removal of the export ban, US oil production has become more sensitive to financial forces. US oil production will be more vulnerable to developments in the financial markets. As shale oil production is an important part of the US economy, any adverse development in shale oil production could adversely affect the US financial sector.

The present study can be extended for different basins, which may have different effects in different domestic markets through refineries and export markets. Thus, shale oil production in different basins may respond differently to various economic variables. This might be captured with a FAVAR model. The effects of microeconomic shocks may fade away or change. This might be analyzed with dynamic VAR modes. These relationships may also charge with the removal of the export ban. Any structural change due to the removal of the ban can be studied.

\section{Note}

1. The impulse response analysis is one method that one can use for inference from a VAR specification. We repeat the same exercises with Garnger Causality tests. The results were mostly robust. These are not reported here but are available from the authors upon request. 
IJESM 15,6

\section{References}

American Petroleum Institute (2018), "Oil and natural gas: supporting the economy, creating jobs", Driving America Forward, available at: www.api.org/ /media/Files/Policy/Taxes/DM2018086_API_Fair_Share_OnePager_FIN3.pdf

Baffes, J., Kose, M.A., Ohnsorge, F. and Stocker, M. (2015), "The great plunge in oil prices: causes, consequences, and policy responses", Development Economics World Bank Group, pp. 1-60, available at: www.banqueducanada.ca/wp-content/uploads/2016/05/great-plunge-oil-prices.pdf

Banerjee, N. (2015), “Can fracking pollute drinking water? Don't ask the EPA”, Inside Climate News, available at: https://insideclimatenews.org/news/02032015/can-fracking-pollute-drinking-waterdont-ask-epa-hydraulic-fracturing-obama-chesapeake-energy

Baumeister, C. and Kilian, L. (2016), "Understanding the decline in the price of oil since June 2014", Journal of the Association of Environmental and Resource Economists, Vol. 3 No. 1, pp. 131-158.

Beattie, A. (2019), "The difference between shale oil and oil shale", Investopedia, available at: www. investopedia.com/articles/investing/080715/difference-between-shale-oil-and-oil-shale.asp.

Bjørnland, H.C., Nordvik, F.M. and Rohrer, M. (2021), "Supply flexibility in the shale patch: evidence from North Dakota", J Appl Econ, Vol. 36, pp. 273-292, doi: 10.1002/jae.2808.

Brittingham, C.M., Maloney, O.K., Farag, M.A., Harper, D.D. and Bowen, H.Z. (2014), "Ecological risks of shale oil and gas development to wildlife", Environmental Science and Technology, Vol. 48 No. 19, pp. 11034-11047, doi: 10.1021/es5020482.

Brown, P.A.S. and Yücel, M.K. (2013), "The shale gas and tight oil boom: U.S. States' economic gains and vulnerabilities", Foreign Relations Council. available at: www.cfr.org/report/shale-gas-andtight-oil-boom

Brune, N. (2015), "The impact of the U.S. Shale boom on Africa", Journal of International Affairs, Vol. 69 No. 1, pp. 101-120. available at: www.jstor.org/stable/jinteaffa.69.1.101

Chen, H., Liu, L., Wang, Y. and Zhu, Y. (2016), “Oil price shocks and U.S. dollar exchange rates”, Energy, Vol. 112, pp. 1036-1048.

Chen, J. (2020), "New York mercantile exchange (NYMEX)”, Investopedia, April 9, available at: www. investopedia.com/terms/n/nymex.asp

Dale, M.S. (2015), "The new economics of oil", Oxford Energy Comment, available at: www. oxfordenergy.org/wpcms/wp-content/uploads/2015/10/The-New-Economics-of-Oil.pdf

Difiglo, C. (2014), "Oil, economic growth and strategic petroleum stocks", Energy Strategy Review, pp. 48-56, doi: 10.1016/j.esr.2014.10.004.

Eberhart, D. (2011), The Economic Impact of U.S. Shale: A Revolution For American Workers And American Industries. CANARYUSA, available at: http://canaryusa.com/wp-content/uploads/ 2014/10/canary-whitepaper-the-economic-impact-of-us-shale.pdf

EIA (2018a), "EIA - 914 monthly crude oil and lease condensate and natural gas production report methodology", U.S. Department of Energy, available at: www.eia.gov/petroleum/production/ pdf/eia914methodology.pdf

EIA (2018b), "Hydraulically fractured horizontal wells account for most new oil and natural gas wells", available at: www.eia.gov/todayinenergy/detail.php?id=34732.

EIA (2019a), "Oil: crude and petroleum products explained oil imports and exports", available at: www. eia.gov/energyexplained/oil-and-petroleum-products/imports-and-exports.php.

EIA (2019b), "Oil: crude and petroleum products explained where our oil comes from", available at: www.eia.gov/energyexplained/oil-and-petroleum-products/where-our-oil-comes-from.php.

Ellwanger, R., Sawatzky, B. and Zmitrowicz, K. (2017), "Factors behind the 2014 oil prices decline", Bank of Canada Review, pp. 1-20, available at: www.bankofcanada.ca/wp-content/uploads/2017/ 11/boc-review-autumn2017-ellwanger.pdf 
Frondel, M. and Horvath, M. (2019), "The US fracking boom: Impact on oil prices", Ruhr Economic Papers, No. 794, ISBN 978- 3- 86788-922- 3, doi: 10.4419/86788922.

Fueki, T., Higashi, H., Higashio, N., Nakajima, J., Ohyama, S. and Yoichiro, T. (2018), "Identifying oil price shocks and their consequences: the role of expectations in the crude oil market", BIS Working Paper No. 725, May 17.

Gupta, K. (2019), "Lack of credit is latest blow to the struggling shale industry", Bloomberg. November 12, available at: www.bloomberg.com/news/articles/2019-11-22/lack-of-credit-is-latest-blow-tothe-struggling-shale-industry

Hiller, J. (2020), "Few US shale firms can withstand prolonged oil price war", Reuters, March 16, available at: www.reuters.com/article/us-global-oil-shale-costs-analysis/few-u-s-shale-firms-canwithstand-prolonged-oil-price-war-idUSKBN2130HL

Huang, H. and Mollick, A.V. (2020), "Tight oil, reat WTI prices and U.S. stocks returns", Energy Economics, Vol. 85, doi: 10.1016/j.eneco.2019.104574.

Kang, W., Ratti, R.A. and Vespignani, J. (2016), "The impact of oil price shocks on the US stock market: a note on the roles of US and non-US oil production”, Economics Letters, Vol. 145 Nos 0165/1765, pp. 176-181, doi: 10.1016/j.econlet.2016.06.008.

Kilian, L. (2009), "Not all oil price shocks are alike: disentangling demand and supply shocks in the crude oil market", American Economic Review, Vol. 99 No. 3, pp. 1053-1069.

Kilian, L. and Park, C. (2009), "The impact of oil price shocks on the U.S. stock market", International Economic Review, Vol. 50 No. 4, pp. 1267-1287.

Koplos, J., Tuccillo, E.M. and Ranalli, B. (2014), "Hydraulic fracturing overview: How, where, and its role in oil and gas", Journal - American Water Works Association), Vol. 106 No. 11, pp. 38-46, available at: www.jstor.org/stable/jamewatworass.106.11.38

Leahy, S. (2014), "Fracking's impact on wildlife remains unknown, study finds", The Guardian available at: www.theguardian.com/environment/2014/aug/13/frackings-impact-on-wildliferemains-unknown-study-finds

McCracken, R. (2015), "Energy economist: Shale oil's response to prices may call for industry re-evaluation”, S\&P Global Platts. available at: https://blogs.platts.com/2015/01/29/shaleconventional-oil/

Manescu, C. and Nuno, G. (2015), "Quantitative effects of the shale oil revolution”, Banco de Espana Working Paper No. 1518, doi: 10.2139/ssrn.2622469

Newell, R.G. and Prest, B.C. (2019), "The unconventional oil supply boom: aggregate price response from microdata", Energy Journal, Vol. 40, pp. 1-30.

Ogunyiola, J.A. (2015), An Analysis of Shale Oil Development and its Implications for OPEC Exporting Nations: Evidence from Nigeria. 8th Annual Conference of The Nigerian Association For Energy Economics On The Future Energy Options: Policy Formulation, Assessment, and Implementation, April 28, available at: https://ssrn.com/abstract= 2721345

Primary Vision (2019), “What is a frac spread?”, available at: www.fracspreadcount.com/learn

Ramady, M. and Mahdi, W. (2015), "OPEC in a shale oil world: Where to next?", Springer International Publication. doi: 10.1007/978-3-319-22371-1

Reiff, N. (2020), "Hedge”, Investopedia, February 1: available at: www.investopedia.com/terms/h/hedge. asp

Salameh, M.G. (2013), Impact of Us Shale Oil Revolution on The Global Oil Market, The Price of Oil and Peak Oil. International Association for Energy Economics (IAEE) available at: www.google.

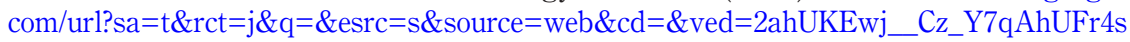
KHV6xDIUQFjAAegQIBhAB\&url=https $\% 3 \mathrm{~A} \% 2 \mathrm{~F} \% 2 \mathrm{Fwww}$.iaee.org $\% 2 \mathrm{Fen} \% 2 \mathrm{Fpublications} \%$ 2Fnewsletterdl.aspx \%3Fid\%3D202\&usg=AOvVaw3PzDWbKvXCR9k5N2NV12UM 
IJESM 15,6

Souther, S., Tingley, M.W., Popescu, V.D., Hayman, D.T., Ryan, M.E., Graves, T.A. and Terrell, K. (2014), "Biotic impacts of energy development from shale: research priorities and knowledge gaps", Frontiers in Ecology and the Environment, Vol. 12 No. 6, pp. 330-338, doi: $10.1890 / 130324$.

Stock, J.H. and Watson, M.W. (2001), "Vector autoregressions", Journal of Economic Perspectives, Vol. 15 No. 4, pp. 101-115, doi: 10.1257/jep.15.4.101.

Valadkhani, A. and Smyth, R. (2017), "How do daily changes in oil prices affect US monthly industrial output?", Energy Economics, Vol. 67, pp. 83-90.

WoodMackenzie (2019), "URTeC 2019 survival of the fittest blog”, July 10, available at: www.woodmac. com/news/feature/urtec-2019-survival-of-the-fittest-blog/

Zhang, D. and Yang, T. (2015), "Environmental impacts of hydraulic fracturing in shale gas development in the United States", Petroleum Exploration and Development, Vol. 42 No. 6, pp. 876-883, doi: 10.1016/S1876-3804(15)30085-9.

\section{Further reading}

Alvares, I.A. and Nino, D.V. (2017), "The oil market in the age of shale oil", ECB Economic Bulletin, Vol. 8, pp. 54-74, available at: www.ecb.europa.eu/pub/pdf/other/ebart201708_01.en.pdf

Amadeo, K. (2020), The S\&P 500 and How It Works. The Balance, March 13, available at: www. thebalance.com/what-is-the-sandp-500-3305888

Chen, X., Wang, M. and Yan, Y.X. (2011), “Accumulation conditions for continental shale oil and gas in the biyang depression”, Oil and Gas Geology, Vol. 32 No. 4, pp. 568-577.

Cunningham, N. (2018), "U.S. Shale's glory days are numbered", Oil Price, October 16, available at: https://oilprice.com/Energy/Crude-Oil/US-Shales-Glory-Days-Are-Numbered.html

Jiang, Z., Zhang, W., Liang, C., Wang, Y., Lui, H. and Chen, X. (2016), "Basic characterisitics and evaluation of shale oil reservoirs", Petroleum Research, Vol. 1 No. 2, pp. 149-168, doi: 10.1016/ S2096-2495(17)30039-X. December

Kelly, S. (2019), "Fracked shale oil wells drying up faster than predicted, wall street journal finds", DESMOG, available at: www.desmogblog.com/2019/01/10/fracking-shale-oil-wells-drying-fasterpredicted-wall-street-journal, January 19

Kilian, L. (2017), “The impact of the fracking boom on Arab oil producers", Energy Journal, Vol. 38 No. 6, pp. 137-160.

Kilian, L. (2015), "How has shale oil affected the global oil price?”, World Economic Forum, available at: www.weforum.org/agenda/2015/01/how-has-shale-oil-affected-the-global-oil-price/

Langer, L., Huppmann, D. and Holz, F. (2016), "Lifting the US crude oil ban: a numerical partical equilibrium analysis", Energy Policy, Vol. 97, pp. 258-266, doi: 10.1016/j.enpol.2016.07.040. October

Lemons, K. (2014), The Shale Revolution and OPEC: Potential Economic Implications of Shale Oil for OPEC and Member Countries. The Larrie and Bobbi Weil Undergraduate Research Award Documents. 5, available at: https://scholar.smu.edu/weil_ura/5

Marfone, P.A. (2013), "Refiners have a new learning curve with shale oil", Hydrocarbon Processing, available at: www.researchgate.net/publication/293134559_Refiners_have_a_new_learning_ curve_with_shale_oil

Maugeri, L. (2013), The Shale Oil Boom: A US Phenomenon Discussion Paper 2013-05, Belfer Center for Science and International Affairs, Harvard Kennedy School. available at: www.belfercenter.org/ publication/shale-oil-boom-us-phenomenon

Medlock, K.B. (2015), "To lift or not to lift? The US crude oil export ban: Implications for price and energy security", James A. Baker III Institute for Public Policy of Rice University: available at: http://bakerinstitute.org/research/lift-or-not-lift-us-crude-oil-export-ban-implications-price-andenergy-security/. 
Speight, J.G. (2019), Shale Oil and Gas Production Processes, in Hammon, K. (Ed.), Gulf Professional Publishing, Cambridge.

United States, Securities and Exchange Commission (2008), CCH SEC Docket, 92(1), July 14, available at: https://books.google.com.tr/books?id=7K1wwwPRuK0C\&printsec $=$ frontcover\&hl=tr\& source=gbs_ge_summary_r\&cad $=0 \# \mathrm{v}=$ onepage $\& \mathrm{q}=$ nymex $\& \mathrm{f}=$ false

\section{Corresponding author}

M. Hakan Berument can be contacted at: berument@bilkent.edu.tr

For instructions on how to order reprints of this article, please visit our website: www.emeraldgrouppublishing.com/licensing/reprints.htm Or contact us for further details: permissions@emeraldinsight.com 